\title{
KAJIAN KONSEPTUAL KONTRIBUSI GAYA BELAJAR TERHADAP PERILAKU BELAJAR
}

Kajian Konseptual Kontribusi Gaya Belajar

\author{
Moh. Sutomo \\ Dosen FTIK IAIN Jember \\ Sutomompd1971@gmail.com
}

\begin{abstract}
Studies on learning styles are always interesting to study, even many studies have emerged, but how the behavioral orientation of each learning style is not so popular to study. That teachers as students need to understand the learning style of learners is indeed a necessity, but how the orientation of learners' behavior with the learning styles they have then is used as feedback for students to evaluate the learning services provided have not been so much described in scientific studies. This paper aims to describe various learning styles and their consequences in the form of learning behavior orientation of the learner, so that the end learners understand how to provide services that satisfy the learning (learners) so that effective and efficient achievement of learning outcomes can be achieved.
\end{abstract}

Keywords: learning style, learning behavior.

\begin{abstract}
Abstrak
Studi tentang gaya belajar selalu menarik untuk di teliti, bahkan sudah banyak kajian-kajian yang muncul, tetapi bagaimana orientasi perilaku dari masing-masing gaya belajar belum begitu populer untuk di kaji. Bahwa guru sebagai pebelajar perlu memahami gaya belajar pembelajar itu memang suatu keharusan, tetapi bagaimana orientasi perilaku pembelajar dengan gaya belajar yang dimiliki kemudian dimanfaatkan sebagai feedback bagi pebelajar untuk mengevaluasi pelayanan pembelajaran yang diberikan belum begitu banyak diuraikan dalam kejian-kajian ilmiah. Tulisan ini bertujuan mendeskripsikan berbagai gaya belajar dan konsekuensinya dalam bentuk orientasi perilaku belajar si pembelajar, sehingga akhir pebelajar memahami bagaimana memberikan layanan yang memuaskan si belajar (pembelajar) sehingga efektif dan efisiensi pencapaian hasil belajar dapat di capai.
\end{abstract}

Kata Kunci: gaya belajar, perilaku belajar.

\section{Pendahuluan}

Tujuan pembelajaran adalah mempengaruhi siswa agar belajar, maka hakekat mengajar adalah upaya membelajarkan siswa ${ }^{1}$. Dalam upaya membelajarkan siswa itu sebenarnya tugas pengajar adalah memberikan pelayanan pada peserta didik dalam bentuk penyampaian pesan berupa materi pembelajaran. Dalam impelementasinya, mengajar yang ideal disampaikan dengan inspiratif,

\footnotetext{
${ }^{1}$ Nyoman S. Degeng, 2013, Ilmu pembelajaran; Klasifikasi Variabel Untuk Pengembangan teori dan Penelitian, (Bandung, Kalam Hidup), 1.
}

Vol. ㄱ. No. 02. Oktober 2019

Jurnal Auladuna | 112 


\section{Mob.Soetomo}

inovatif, menyenangkan, menantang dan memotivasi (I2M3) (standar proses) ${ }^{2}$. Ada beberapa prasyarat pembelajaran sebagai suatu layanan akademik akan berhasil antara lain pemahaman karakteristik siswa. Pada pembelajaran pada perguruan tinggi, maka karakteristik mahasiswa yang sedang belajar merupakan salah satu ciri khas individu yang di miliki dan itu memberikan perbedaan antar mahasiswa satu dengan lainnya.

Salah satu karakteristik belajar yang yang sering dimiliki oleh peserta didik tetapi luput dari perhatian pendidik (dosen) adalah berkaitan dengan proses menyerap, mengolah, dan menyampaikan informasi (pesan) yaitu gaya belajar peserta didik. Gaya belajar merupakan modalitas belajar yang sangat penting, informasi terkait karakteristik gaya belajar mahasiswa yang akan dibelajarkan, sangat penting bagi pendidik (dosen) untuk meningkatkan kualitas pembelajarannya. Karena dengan memahami gaya belajar peserta didik memudahkan kita sebagai pendidik (dosen) dalam memberikan pelayanan pembelajaran di kelas dalam mengarahkan terjadinya perilaku belajar ${ }^{3}$.

Pembelajaran sebagai bagian dari proses komunikasi, membutukan pemahaman yang sama tentang situasi, kondisi, sarana, dan juga psikologis. Untuk itu perlu dibangun suasana yang kondusif untuk memaksimalkan komunikasi dalam pembelajaran. Suasana yang kondusif memungkinkan efektifnya komunikasi yang terbuka, simpati dan diharapkan mampu meminimalisir kemungkinan konflik antara pembelajar dengan pebelajar dalam proses pembelajaran. Pemahaman tentang gaya belajar mahasiswa memungkinkan dosen belajar juga memahami karakter individu mahasiswa dalam belajar, sebab jika strategi mengajar guru sama dengan gaya belajar siswa, maka tidak ada pelajaran yang sulit ${ }^{4}$.

Untuk dapat mengajar dengan baik, sebelum mengajar seorang pengajar harus dapat menjawab tiga pertanyaan pokok yaitu: a) Apakah pelajar akan dapat belajar?, b) Bagaimanakah mengorganisir pelajar agar mereka dapat mencapai tujuan pembelajarannya dengan baik?, c) Hal-hal apa yang mesti harus dilakukan berkaitan dengan perbedaan individu yang dimiliki oleh para pelajar? ${ }^{5}$. Dengan

\footnotetext{
2 Lampiran: Peraturan Menteri Pendidikan Dan Kebudayaan Nomor 22 TAHUN 2016 tentang Standar proses Pembelajaran, 1.

${ }^{3}$ Haddioui, I. E., \& KHALDI, M. (2012). Learning Style and Behavior Analysis A Study on the Learning Management. International Journal of Computer Applications , 56 (4), 9-15.

${ }^{4}$ Munif Chatib, 2014. Orangtuanya Manusia: Melejitkan Potensi dan Kecerdasan dengan Menghargai Fitrah Setiap Anak. Bandung: PT Mizan Pustaka, 100

5 Soedijanto Padmowihardjo, Modul: Psikologi Belajar Mengajar, di unduh pada epository.ut.ac.id/4427/1/LUHT4232-M1. pdf, 3 Juli 2019.
}

Vol. I. No. 02. Dktober 2019

Jurnal Auladuna | 113 
Kajian Konseptual Kontribusi Gaya Belajar melihat tiga pertanyaan tersebut, maka keberhasilan dalam mengajar sangat penting untuk memerhatikan pemahaman pengajar terhadap siapa yang belajar, termasuk bagaimana gaya belajar dan perilaku orang yang belajar. Pemahaman ini penting untuk memberikan layanan membantu si belajar dalam melakukan kegiatan belajar, karena esensi mengajar adalah memberikan bantuan (layanan) pada seseorang agar terjadi proses belajar ${ }^{6}$.

Dalam pembelajaran kontruktifisme, pemahaman tentang gaya belajar memberikan informasi bagaimana kehendak dan model orang yang belajar, sehingga pemahaman ini akan meminimalisir konflik antara pengajar dengan individu atau kelompok yang belajar. Karena pemahaman gaya belajar akan mengantarkan pengajar pada pemahaman perilaku belajar dengan gaya belajar yang menjadi kekhasan dari individu atau kelompok yang sedang belajar. Pemahaman ini menjadi modal awal dalam memberikan layanan belajar.

Studi tentang gaya belajar dan perilaku belajar telah banyak dilakukan dan selalu menarik perhatian mengingat perannya yang penting dalam pencapaian hasil belajar. Di dunia pendidikan yang terpenting adalah bagaimana mengajar, membimbing, dan menyarankan suatu strategi belajar yang efektif untuk setiap gaya belajar ${ }^{7}$. Saran tersebut penting bagi mahasiswa dan mahasiswa perguruan tinggi untuk membangun komunikasi pengajar dan mahasiswa sehingga umpan balik yang diterima menjadi perilaku belajar yang efektif.

Perilaku belajar menyangkut cara atau tindakan yang berisi sikap atas pelaksanaan teknikteknik belajar yang dilaksanakan individu atau siapapun juga dalam waktu dan situasi belajar tertentu ${ }^{8}$. Oleh karena itu perilaku belajar menyangkut perilaku individu dalam belajar. Adapun indikator dari perilaku belajar itu meliputi: a) Perilaku belajar dalam mengikuti pelajaran, b) Perilaku belajar dalam mengulangi pelajaran, c) Perilaku belajar dalam membaca buku, d) Perilaku belajar dalam mengunjungi perpustakaan, e) Perilaku belajar dalam menghadapi ujian ? Sedangkan pada pendidikan tinggi, Suryaningsum dkk (2005), merumuskan perilaku belajar mahasiswa umumnya

\footnotetext{
${ }^{6}$ Nyoman S. Degeng, 2013, IImu pembelajaran; Klasifikasi Variabel Untuk Pengembangan teori dan Penelitian, (Bandung, Kalam Hidup), 36

${ }^{7}$ Bobbi DePorter, Mark Reardon,\&Sarah Singer-Nourie, 2014, Quantum Teaching. Bandung: PT Mizan Pustaka, 99.

${ }^{8}$ Wasty Soemanto, Psikologi Pendidikan (Jakarta: Rineka Cipta), 6.

${ }^{9}$ Endang Saryanti, Kajian Empiris Atas Perilaku Belajar, Efikasi Diri dan Kecerdasan Emosional yang Berpengaruh Pada Stress Kuliah Pada Mahasiswa Akuntansi Perguruan Tinggi Swasta di Surakarta Dalam Jurnal Ekonomi Bisnis dan Perbankan, vol 19 no. 18. ISSN: 22527885. Agustus 2011.
} 
Moh.Soetomo

meliputi empat bagian pokok yaitu a) kebiasaan mengikuti pelajaran, b) kebiasaan membaca buku, c) kunjungan ke perpustakaan, d) kebiasaan menghadapi ujian ${ }^{10}$.

Pemahaman tentang perilku belajar sebenarnya bentuk pengakuan seorang pendidik, bahwa orang yang belajar itu memiliki pola perilaku berbeda dalam belajar. Hal ini kemudian akan memudahkan pendidik dalam memberikan pelayanan dalam rangkah mendorong terjadinya terjadiya proses belajar.

\section{Gaya Belajar}

Secara mudah gaya belajar sebagai cara individu dalam memproses informasi dengan tujuan mempelajarai dan menerapkannya. Karena bersifat individu, maka setiap individu memiliki perbedaan dalam memahami dan memproses informasi yang diterimanya. Gaya belajar adalah cara yang lebih kita sukai dalam melakukan kegiatan berpikir, memproses dan mengerti suatu informasi ${ }^{11}$. Gaya belajar juga kebiasaan yang mencerminkan cara kita memperlakukan pengalaman yang kita peroleh melalui modalitas ${ }^{12}$. Sedangkan Bobby De Porter dan Mike Hernacki menjelaskan bahwa gaya belajar adalah kombinasi dari bagaimana ia menyerap. dan kemudian mengatur serta mengolah informasi ${ }^{13}$. Meskipun gaya belajar berbeda dengan modalitas namun keduanya memiliki keterkaitan yakni gaya belajar akan muncul jika kita telah mengenali modalitas terlebih dahulu.

Menyadari bagaimana cara menyerap dan mengolah informasi, dapat menjadikan belajar dan berkomunikasi lebih mudah. Di sekolah para guru hendaknya menyadari bahwa setiap siswa memiliki cara dan gaya yang berbeda dalam mempelajari informasi baru. Mengetahui gaya belajar yang berbeda ini akan membantu para guru di mana pun untuk dapat mendekati semua atau hampir semua siswa dengan menyampaikan informasi dengan gaya yang berbeda-beda. Walaupun masing-masing peneliti menggunakan istilah yang berbeda dan menemukan berbagai cara untuk mengatasi gaya belajar seseorang, telah disepakati secara umum adanya dua kategori utama tentang bagaimana kita belajar. Pertama, bagaimana kita menyerap informasi dengan mudah (modalitas) dan kedua, cara kita

${ }^{10}$ Suryaningsum, Sri Sucahyo Heriningsih, 2005, Kajian Empiris Atas Pengaruh Kecerdasan Emosional Mahasiswa Akuntansi Terhadap Stres Kuliah, Simposium Nasional Mahasiwa dan Alumni Pasca Sarjana Ilmu Ekonomi UGM.

${ }^{11}$ Adi W. Gunawan, Genius Learning Strategy Petunjuk Praktis Untuk Menerapkan Accelarated Learning, (Jakarta: PT Gramedia Pustaka Utama, 2003), 139

${ }^{12}$ Bob Samples, Revolusi Belajar untuk Anak: Panduan Belajar Sambil Bermain untuk Membuka Pikiran Anak-anak Anda, (Bandung: Kaifa, 2002), 146

${ }^{13}$ Bobby DePorter dan Mike Hemacki, 2011, terjemahan Alwiyah Abdurrahman, Quantum Learning nyaman dan menyengkan (Bandung: Kaifa), 110

Vol. ㅁ․ №. Q2. ktober 2019

Jurnal Auladuna | 115 

mengatur dan mengolah informasi tersebut (dominasi otak). Gaya belajar seseorang adalah kombinasi dari bagaimana ia menyerap, dan kemudian mengatur serta mengolah informasi ${ }^{14}$.

Pemahaman tentang karakteristik gaya belajar siswa (si belajar) secara otomatis akan mendorong para pengajar (guru) untuk berusaha menyesuaikan lingkungan pembelajaran dengan kecenderungan siswa dapat berakibat dalam peningkatan prestasi dan perbaikan perilaku ${ }^{15}$.

Ada beberapa kajian tentang gaya belajar (learning style), menurut Gregorc seperti dikutip Bobbi Deporter \& Mike Hernacki (2010) terdapat empat kombinasi kelompok perilaku yang disebut dengan gaya berpikir, diantara gaya ini adalah sekuensial konkret, sekuensial abstrak, acak konkret, acak abstrak. Orang yang termasuk dalam dua kategori "sekuensial" cenderung memiliki dominasi otak kiri, sedang orang-orang yang berpikir secara "acak" biasanya termasuk dalam dominasi otak kanan ${ }^{16}$.

Kajian Dunn dan Dunn sebagaimana dikutip Jacobsen (2009) Salah satu pendekatan dalam gaya-gaya belajar yang paling populer dikembangkan oleh Ken dan Rita Dunn yakni para pendidik menemukan bahwa para siswa berbeda dalam hal tanggapan mereka terhadap tiga dimensi kunci pembelajaran: (seperti suara, cahaya, dan temperatur), stimulus fisik (contoh lisan versus tulis), struktur dan dukungan (contoh bekerja sendiri atau dalam kelompok) ${ }^{17}$.

Gunawan (2003) menjelaskan ada kajian yang didasarkan pada Neuro-Linguistic Programming yang dikembangkan oleh Richard Bandler dan John Grinder dalam model strategi komunikasi, menurutnya ada preferensi bagaimana kita menciptakan dan memberikan arti pada suatu informasi. Secara umum, kita menggunakan tiga preferensi sensori, yaitu berdasarkan pada visual (penglihatan), auditori (pendengaran) dan kinestetik (sentuhan dan gerakan). Ini yang dikenal dengan nama modalitas V-A-K, yang untuk selanjutnya dikenal dengan istilah gaya belajar V-A-K ${ }^{18}$.

\footnotetext{
${ }^{14}$ H. Hamruni, 2009, Strategi dan Model-model Pembelajaran Aktif Menyenangkan, (Yogyakarta: Fakultas Tarbiyah UIN Sunan Kalijaga), 65

${ }^{15}$ David A. Jacobsen, dkk, Methods For Teaching Metode-Metode Pengajaran Meningkatkan Belajar Siswa TK-SMA Edisi ke-8, (Yogyakarta: Pustaka Pelajar, 2009), 28

${ }^{16}$ Bobby DePorter dan Mike Hemacki, 2011, terjemahan Alwiyah Abdurrahman, Quantum Learning , 124

${ }^{17}$ David A. Jacobsen, dkk, 2009, Methods For Teaching Metode-Metode Pengajaran Meningkatkan Belajar Siswa TK-SMA Edisi ke-8, 279

${ }^{18}$ Adi W. Gunawan, Genius Learning Strategy: Petunjuk Praktis Untuk Menerapkan Accelarated Learning, (Jakarta: PT Gramedia Pustaka Utama, 2003), 143
}

Jurnal Auladuna| 116

Vol. ㄱ. No. Q2. पktober 


\section{Mob.Soetomo}

Gaya belajar V-A-K) yang dikenal dengan tiga gaya belajar yaitu gaya belajar viasual, gaya belajar auditori/auditif, gaya belajar kinestetik memiliki beberapa indikator yang memberikan perbedaan pada ketiga gaya belajar tersebut.

\section{a. Indikator gaya belajar V (visual):}

1) Belajar dengan cara visual

2) Pembaca yang cepat dan tekun.

3) Sulit menerima intruksi verbal

4) Sering menjawab pertanyaan dengan jawaban singkat

5) Kebiasaan rapi dan teratur

6) Tidak terganggu dengan keributan.

\section{b. Indikator gaya belajar A (auditif):}

1) Belajar dengan mendengarkan

2) Baik dalam aktivitas lisan

3) Merasa sulit untuk menulis tetapi hebat dalam bercerita

4) Mudah terganggu oleh keributan

5) Memiliki kepekaan terhadap musik.

\section{c. Indikator gaya belajar K (kinestetik):}

1) Belajar dengan aktivitas fisik

2) Berorientasi pada fisik dan bergerak

3) Peka terhadap ekspresi dan bahasa tubuh

4) Lemah dalam aktivitas verbal ${ }^{19}$

Masing-masing gaya belajar turut memberikan warna pada pola belajar pada individu. Oleh karena dengan memahami gaya belajar seseorang secara otomatis, akan membawa pemahaman yang kuat tentang bagaimana individu yang sedang belajar itu berperilaku dalam rangkah belajar. Akibat dari pemahaman inilah pada akhirnya juga dapat di pahamai model pendekatan pembelajaran, dan strategi pembelajaran yang dilakukan oleh individu yang sedang belajar. Sehingga akhirnya akan ditemukan model pelayanan yang bisa memaksimalkan terjadinya proses belajar itu sendiri.

\section{Perilaku Belajar}

19 Bobby DePorter dan Mike Hemacki, 20011, terjemahan Alwiyah Abdurrahman, Quantum Learning nyaman 120.

Vol. ㄱ. No. Q2. Qktober 2019

Jurnal Auladuna | 117 
Kajian Konseptual Kontribusi Gaya Belajar

Setiap individu yang sedng belajar pastilah memiliki perilaku belajar, karena hal ini diri individu yang sedang belajar dalam menanggapi dan meresponi setiap kegiatan belajar mengajar yang terjadi. Perilaku belajar juga berkaitan dengan cara belajar yang dilakukan oleh individu yang sedang belajar (siswa/mahasiswa) itu sendiri, sehingga perilaku belajar adalah merupakan cara atau tindakan yang berisi sikap atas pelaksanaan teknik-teknik belajar yang dilaksanakan individu atau siapapun juga dalam waktu dan situasibelajar tertentu ${ }^{20}$.

Perilaku belajar adalah suatu sikap yang muncul dari diri siswa dalam menanggapi dan meresponi setiap kegiatan belajar mengajar yang terjadi, menunjukkan sikapnya apakah antusias dan bertanggung jawab atas kesempatan belajar yang diberikan kepadanya. Perilaku belajar memiliki dua penilaian kualitatif yakni baik dan buruk tergantung kepada individu yang mengalaminya, untuk meresponinya dengan baik atau bahkan acuh tak acuh. Perilaku belajar juga berbicara mengenai cara belajar yang dilakukan oleh siswa itu sendiri, sehingga dapat disimpulkan bahwa perilaku belajar adalah merupakan cara atau tindakan yang berisi sikap atas pelaksanaan teknik-teknik belajar yang dilaksanakan individu atau siapapun juga dalam waktu dan situasi belajar tertentu ${ }^{21}$

Perilaku belajar yang baik berhubungan dengan beberapa hal yaitu:

a. Perilaku belajar dalam mengikuti pelajara

Perilaku belajar disini bukan hanya sekedar untuk mendengar dan mencatat ceramah dari guru tetapi lebih kepada mendengar dan menimbang secara selektif atas apa yang telah diungkapkan oleh guru ketika proses belajar mengajar berlangsung. Kebiasaan belajar dalam mengikuti pelajaran merupakan salahsatu faktor penunjang tercapainya prestasi belajar siswa. Sehinggadalam upaya untuk mencapai hasil belajar yang terbaik maka diharapkan keaktifan dari siswa untuk mempunyai sikap dan carabelajar yang sistematis. Dimana cara belajar yang dilakukanmerupakan suatu kecakapan yang pada nantinya akan dimiliki sebagaihasil belajarnya, yang diperoleh lewat latihan-latihan sehingga lama-kelamaan menjadi suatu kebiasaan yang melekat dalam dirinya. Kebiasaan mengikuti pelajaran berakar dari kebiasaan belajaryang memiliki makna merupakan perilaku dari siswa dalam mengikutiproses belajar secara tepat, teratur dan berkesinambungan dari waktuke waktu sehingga pada akhirnya dapat menimbulkan ciri bagiseseorang yang melaksanakan proses ini.

\footnotetext{
${ }^{20}$ Wasty Soemanto. 2006. Psikologi Pendidikan: Landasan Kerja Pemimpin Pendidikan(Cetakan Ke- 5). (Jakarta: Rineka Cipta), 6

${ }^{21}$ Wasty Soemanto, 2010, Psikologi Pendidikan, (Jakarta: Rineka Cipta),6.
}

Jurnal Auladuna| II8

Vol. DI. No. Q2. Oktober

2019 


\section{Moh.Soetomo}

b. Perilaku belajar dalam mengulangi pelajaran

Penjelasan guru yang diterima oleh siswa terkadang atau bahkan seringkali tidak membawa kesan yang baik, karena terkadang masih ada kesan-kesan tertentu yang masih samar-samar dalam ingatan akan pelajaran atau materi yang didapat pada saat proses belajar mengajar. Oleh karena itu dibutuhkan adanya pengulangan atau pemantapan dari siswa untuk membantu memperjelas semua kesan yang masih samar samar tadi. Belajar dengan cara mengulang bisa dibantu dengan membandingkan antara bahan pelajaran yang baru saja diserap di ruang belajar dengan literatur yang dimiliki oleh siswa tersebut. Dimana pada dasarnya hal seperti ini dimaksudkan untuk mempermudah pemahaman.

c. Perilaku belajar dalam membaca buku

Membaca adalah aktivitas yang kompleks yang melibatkan berbagai faktor yang datangnya dari dalam diri pembaca dan faktor luar. Secara garis besar, aktivitas membaca berkaitan dengan dua hal pokok, yaitu pembaca dan bahan bacaan, sehingga sejalan dengan itu diperlukan modal untuk dapat memperlancar proses membaca dari seorang pembaca yakni pengetahuan dan pengalaman, kemampuan berbahasa, pengetahuan tentang teknik membaca dan tujuan dari membaca.

Membaca yaitu kegiatan melihat serta memahami isi dari yang tertulis dengan melisankan atau hanya dalam hati. Membaca memiliki pengaruh yang besar terhadap belajar. Membaca untuk keperluan belajar haruslah menggunakan sumber daya yang dimiliki oleh siswa itu dengan tepat yakni dengan mulai untuk memperhatikan judul-judul atau bab, topik-topik utama yakni dengan tetap berorientasi pada kebutuhan dan tujuan. Selain itu perilaku yang baik yang dapat ditunjukkan saat membaca yaitu ketika membaca buatlah catatan catatan yang dianggap perlu atau juga dapat dilakukan dengan mencatat setiap pertanyaan yang ada dibenak kita bila perlu dengan alternatif jawabannya.

d. Perilaku belajar dalam mengunjungi perpustakaan.

Belajar identik dengan kegiatan yang berhubungan dengan membaca dan mencari sumber bacaan dari berbagai refrensi. Untuk memenuhinya seorang siswa dapat memperolehnya dari sumber sumber yang dianggap relevan dan mampu untuk menjawab kebutuhan akan informasi dan pengetahuan yang dibutuhkan oleh siswa tersebut. Perpustakaan menyediakan berbagai macam buku sehingga siswa dapat mencari bahan pelajaran di perpustakaan sekolah maupun di perpustakaan umum 
e. Perilaku belajar dalam menghadapi ujian.

Saat menghadapi tes atau ujian, biasanya seorang siswa tidak akan mengalami kesulitan yang berarti jikalau ia sudah mengadakan persiapan yang baik dengan belajar semaksimal mungkin. Persiapan menghadapi ujian adalah persiapan yang dilakukan oleh siswa dalam mengatur dan melaksanakan kegiatan belajarnya sehingga materi materi pelajaran yang telah diterimanya dapat dikuasai. Dengan mengetahui jenis ujian yang akan dihadapi maka akan membuat persiapan lebih mudah. Semakin baik kita belajar maka semakin baik pula nilai yang akan kita raih. Pada dasarnya tujuan ujian adalah untuk mengukur cara belajar dan kemampuan dari mengatur setumpukmateri, serta sekaligus juga untuk mengukur pengetahuan mengenai materi-materi yang telah dipelajari ${ }^{22}$.

Sedangkan Suryaningsum dkk (2008), membagi perilaku belajar kaitannya dengan respon ndividu yang sedang belajar meliputi 4 bentuk yang sudah umum yaitu a) kebiasaan mengikuti perkualiahan, b) Kebiasaan Membaca Buku, c) kebiasaan berkunjung ke Perpustakaan, d) Kebiasaan Menghadapi Ujian ${ }^{23}$.

Perwujudan perilaku-perilaku belajar biasanya lebih sering tampak dalam perubahan-perubahan sebagai berikut:

a) Kebiasaan

Setiap individu (siswa) yang telah mengalami proses belajar, kebiasaan-kebiasaannya akan tampak berubah. Kebiasaan itu timbul karena proses penyusunan kecenderungan respon dengan menggunakan stimulus yang berulang-ulang. Dalam proses belajar, pembiasaan juga meliputi pengurangan perilaku yang tidak diperlakukan. Karena proses pengurangan inilah muncul suatu pola bertingkah laku yang relatif menetap dan otomatis.

b) Keterampilan

Keterampilan adalah kegiatan yang berhubungan dengan urat urat saraf dan otot-otot yang lazimnya tampak dalam kegiatan jasmaniah seperti menulis, mengetik, olahraga dan sebagainya. Meskipun sifatnya motorik, tetapi keterampilan itu memerlukan koordinasi gerak yang diteliti dan kesadaran yang tinggi. Menurut Rebber yang dikutip oleh Tohirin, keterampilan adalah kemampuan

22 Endang Saryanti, 2011, Kajian Empiris Atas Perilaku Belajar, Efikasi Diri dan KecerdasanEmosional yang Berpengaruh Pada Stress Kuliah Pada Mahasiswa Akuntansi Perguruan TinggiSwasta di Surakarta, Jurnal Ekonomi Bisnis dan Perbankan, 19(18) 2252-7885.

${ }^{23}$ Suryaningsum dkk.(2008). Kajian Empiris Atas Perilaku Belajar dan kecerdasan Emosional dalam Mempengaruhi stres Kuliah mahasiswa Akuntansi. Simposium Nasional Akuntansi (SNA) Ke XI Pontianak, 23-24 Juli 2008

Jurnal Auladuna| 120

Vol. DI. No. 02. Oktober

2019 


\section{Moh.Soetomo}

melakukan pola-pola tingkah laku yang kompleks dan tersusun rapi secara mulus dan sesuai dengan keadaan untuk mencapai hasil tertentu. Keterampilan bukan hanya meliputi gerakan motorik saja, melainkan juga pengejawantahan fungsi mental yang bersifat kognitif.

\section{c) Pengamatan}

Menurut Muhibbin Syah yang dikutip oleh Tohirin, pengamatan artinya proses menerima, menafsirkan dan memberi arti rangsangan yang masuk melalui indra-indra seperti mata dan telinga. Berkat pengalaman belajar, seorang siswa akan mampu mencapai pengamatan yang benar objektif sebelum memperoleh pengertian. Pengamatan yang salah akan mengakibatkan timbulnya pengertian yang salah pula.

d) Berpikir asosiatif dan daya ingat

Berpikir asosiatif adalah berpikir dengan cara mengasosiasikan sesuatu dengan lainnya. Berpikir asosiatif itu merupakan proses pembentukan hubungan antara rangsangan dengan respon. Kemampuan siswa untuk melakukan hubungan asosiatif yang benar amat dipengaruhi oleh tingkat pengertian atau pengetahuan yang diperoleh dari hasil belajar. Sedangkan daya ingat yaitu merupakan perwujudan belajar, sebab merupakan unsur pokok dalam berpikir asosiatif. Jadi, siswa yang telah mengalami proses belajar akan ditandai dengan bertambahnya simpanan materi (pengetahuan dan pengertian) dalam memori, serta meningkatnya kemampuan menghubungkan materi tersebut dengan situasi atau stimulus yang sedang ia hadapi.

e) Berpikir rasional dan kritis

Berpikir rasional dan kritis adalah perwujudan perilaku belajar, terutama yang bertalian dengan pemecahan masalah (problem solving). Umumnya, siswa yang berpikir rasional akan menggunakan prinsip-prinsip dan dasar-dasar pengertian dalam menjawab pertanyaan. Dalam berfikir rasional, siswa dituntut menggunakan logika (akal sehat) untuk menentukan sebab akibat, menganalisis, menarik kesimpulan-kesimpulan dan bahkan juga menciptakan hukum-hukum (kaedah teoritis) dan ramalan-ramalan.

f) Sikap

Sikap adalah pandangan atau kecenderungan mental. Pada prinsipnya sikap adalah kecenderungan individu (siswa) untuk bertindak dengan cara tertentu. Perwujudan perilaku belajar siswa siswa akan ditandai dengan munculnya kecenderungan kecenderungan baru yang telah berubah (lebih maju dan lugas) terhadap suatu objek, tata nilai, peristiwa dan sebagainya. 
g) Inhibisi

Kajian Konseptual Kontribusi Gaya Belajar

Inhibisi adalah upaya pengurangan atau pencegahan timbulnya suatu respon tertentu karena adanya proses respon lain yang sedang berlangsung. Dalam kaitannya dengan belajar, inhibisi bermakna kesanggupan siswa untuk mengurangi atau menghentikan tindakan yangtidak perlu, lalu memilih atau melakukan tindakan lainnya yang lebih baik ketika ia berinteraksi dengan lingkungannya.

h) Apresiasi

Apresiasi adalah gejala ranah afektif yang umumnya ditujukan pada karya-karya seni budaya seperti seni sastra, musik, lukis dan drama.

i) Tingkah laku afektif

Tingkah laku afektif adalah tingkah laku yang menyangkut keanekaragaman perasaan seperti takut, marah, sedih, gembira, kecewa, senang, benci dan was-was. Tingkah laku seperti ini tidak terlepas dari pengalaman belajar. Oleh karena itu, ia dianggap sebagai perwujudan perilaku belajar ${ }^{24}$.

\section{Gaya belajar menuju perilaku belajar}

Gaya belajar seseorang adalah bagaimana seorang siswa menyerap, mengatur serta mengolah informasi ${ }^{25}$. Gaya belajar erat kaitannya dengan kekuatan yang tersembunyi yang ada pada diri siswa yang sednag belajar. Jika gaya belajar mampu di optimalkan, akan memberikan kekuatan yang luar biasa dalam perolehan hasil belajar. Berdasarkan hasil penelitian yang telah dilakukan, rata-rata siswa memiliki lebih dari satu gaya belajar. Dengan kata lain siswa mampu menyerap informasi dengan mudah jika siswa mampu memadukan ketiga gaya belajar yang ada ${ }^{26}$. Guru sebagai tenaga pendidik juga harus mampu mengkombinasikan cara mengajar dengan berbagai gaya belajar yang dimiliki siswa.

Gaya belajar yang optimal mampu memberikaan dorongan tumbuhnya motivasi belajar. Hal ini terlihat dari hasil penelitian, Hasil penelitian ini juga sesuai dengan hasil penelitian yang dilakukan oleh Hariani (2016), tentang "Kontribusi Gaya Belajar dan Motivasi Belajar Terhadap Hasil Belajar

\footnotetext{
24 Muhibbin Syah, 2011, Psikologi Belajar (Jakarta: Rajawali Pers)120-125

${ }^{25}$ Bobby DePorter dan Mike Hemacki, 2011, terjemahan Alwiyah Abdurrahman, Quantum Learning nyaman dan menyengkan (Bandung: Kaifa), 110.

${ }^{26}$ Ningrat, S. P., Tengeh, I. M., \& Sumantri, M. (2018). Kontribusi Gaya Belajar Dan Motivasi Belajar Terhadap Hasil Belajar Bahasa Indonesia. Jurnal IImiah Sekolah Dasar, 2 (3), 257-265.
}

Jurnal Auladuna| 122

Vol. OI. No. Q2. Oktober

2019 


\section{Mob.Soetomo}

Mata Pelajaran TIK Siswa Kelas VIII SMP Kartika 1-6 Padang”. Bahwa (a) gaya belajar memberikan kontribusi sebesar 44,35\% terhadap hasil belajar siswa, (b) motivasi belajar memberikan kontribusi sebesar 24,50 \% terhadap hasil belajar siswa, (b) gaya belajar dan motivasi belajar secara bersamasama memberikan kontribusi sebesar 51,55\% terhadap hasil belajar siswa ${ }^{27}$. Demikain Khoeron (2014) yang meneliti tentang "Pengaruh Gaya Belajar terhadap Prestasi Belajar Peserta Didik pada Mata Pelajaran Produktif' bahwa gaya belajar mempunyai kontribusi sebesar 52\% terhadap hasil belajar, dengan gaya belajar visual sebesar 35,2\%; auditori sebesar 55,2\%; dan kinestetik sebesar $29,6 \%{ }^{28}$.

Kondisi ini menunjukkan bahwa gaya belajar mampu mendorong semakin maksimalnya motivasi belajar untuk mendorong perolehan hasil belajar. Hasil belajar tidak diperoleh begitu saja, tetapi melalui tahapan dalam belajar yang kita kenal dengan perilaku belajar. Munculnya kebiasaan, keterampilan, pengamatan, berfikir asosiatif dan daya ingat, berfikir rasional dan kritis, bersikap, inhibisi, apresiasi dan perilaku afektif adalah wujud dari perilaku belajar yang melekat secara individu dalam diri orang yang belajar.

Perilaku belajar yang demikian tersebut nampak jelas kemudian dalam perilaku riil dalam belajar, misalnya perilakau belajar dalam mengikuti pelajaran (perkuliahan), perilaku belajar dalam mengulangi pelajaran, perilaku belajar dalam membaca buku, perilaku belajar dalam mengunjungi perpustakaan, perilaku belajar dan perilaku belajar dalam menghadapi ujian.

Hasil penelitian Endang Nugraheni (2006) menunjukkan bahwa gaya belajar auditorial mendominasi dalam hal kecepatan berbicara dan senang mendengarkan. Kemampuan berbicara ini adalah akibat dari perilaku belajar dalam membaca. Sedangkan gaya belajar visual cenderung berbicara dengan singkat dan tidak senang mendengarkan pembicaraan panjang, gaya belajar visual juga memiliki kemampuan mengingat informasi yang cukup tinggi. Sebaliknya gaya belajar kinestetik cenderung memiliki kemampuan berbicara dengan menggunakan isyarat tubuh dan gerakan-gerakan ekspresif, oleh karena itu gaya belajar kinestetik kesulitaan dalam mengingat dengan cepat tetapi

${ }^{27}$ Hariani, V. 2016. “Kontribusi Gaya Belajar Dan Motivasi Belajar Siswa Terhadap Hasil Belajar Pada Mata Pelajaran TIK Siswa Kelas VIII SMP Kartika 1-6 Padang”, Jurnal Pendidikaan UBH, 1(2) 62-75.

28 Khoeron, I. R. 2014. "Pengaruh Gaya Belajar terhadap Prestasi Belajar Peserta Didik pada Mata Pelajaran Produktif". Jurnal IImiah Pendidikan Teknik Mesin UPI, 1(2), 112-126.

Vol. I. No. Q2. Oktober 20IG

Jurnal Auladuna | I23 
Kajian Konseptual Kontribusi Gaya Belajar mudah dalam hal memperagakan/ rekontruksi ulang suatu obyek. Sedangkan dalam hal menghadapi ujian, gaya belajar visual cenderung memanfaatkan membaca sumber dengan baik, sedangkan auditif memiliki kecenderungan mengikuti pelajaran/ perkuliahan dengan efektif mendengarkan penjelasan guru/dosen/teman dalam pelajaran atau diskusi dan bisa dipastikan senang mengunjungi pusat sumber belajar (perpustakaan). Gaya belajar auditif cenderung diskusi dengan teman sejawat untuk mengulang-ulang pelajaran/ penjelasan, gaya belajar kinestetik kecenderungan untuk mengunjungi perpustakaan atau laboratorium untuk mengulang parktek kerja yang telah dilakukan ${ }^{29}$. Oleh sangat ideal jika siswa memahami gaya belajar dengan mengelaborasi beberapa gaya belajar yang di miliki untuk memperkuat motivasi belajar, sehingga maksimal dalam perilaku belajar yang dilakukan. Dengan demikian potensi untuk meraih perolehan belajar yang optimal menjadi sebuah kenyataan yang tak terbantakan.

\section{Kesimpulan}

Bahwa gaya belajar dengan tiga ketegorinya yaitu gaya belajar visual, auditif dan kinestetik merupakan modalitas dalam belajar. Gaya belajar memberikan secara teoritik memberikan kontribusi pada perilaku belajar dalam mendorong perolehan hasil belajar. Hal ini secara teoritik dapat diuraikan bahwa gaya belajar yang dikelola secara optimal akan memudahkan si belajar dalam melakukan perilaku belajar secara optimal pula. Oleh karena itu perlu kepercayaan dalam mengelola dan mengelaborasi beberapa gaya belajar yang dimiliki si belajar, agar perilaku belajar juga semakin optimal.

Optimalnya perilaku belajar berperan semakin efektif dan efisiensi dalam perolehan hasil belajar. Kondisi ini perlu dipahami oleh guru dalam mengelola pembelajaran agar seoptimal pula dalam memberikan layanan untum terjadinya proses belajar. Tanpa pemahaman yang baik tentang gaya belajar dan perilaku belajar, maka layanan proses belajar juga tidak akan efektif dan efisien. Sehingga perolehan belajar juga kurang memuaskan.

\section{Daftar Rujukan}

\footnotetext{
${ }^{29}$ Nugrahen, E., \& Pangaribuan, N. (2006). Gaya Belajar dan Strategi Belajar Mahasiswa Jarak Jauh: Kasus di Universitas Terbuka. 7 (1), 68-82.
}

Jurnal Auladuna| 124

Vol. OI. No. Q2. Uktober

2019 
Moh.Soetomo

Bobbi DePorter, Mark Reardon,\&Sarah Singer-Nourie, 2014, Quantum Teaching. Bandung: PT Mizan Pustaka

Chatib, Munif, 2014. Orangtuanya Manusia: Melejitkan Potensi dan Kecerdasan dengan Menghargai Fitrah Setiap Anak. (Bandung: PT Mizan Pustaka)

David A. Jacobsen, dkk, 2009, Methods For Teaching Metode-Metode Pengajaran Meningkatkan Belajar Siswa TK-SMA Edisi ke-8, (Yogyakarta: Pustaka Pelajar)

Degeng, Nyoman S., 2013, Ilmu pembelajaran; Klasifikasi Variabel Untuk Pengembangan teori dan Penelitian, (Bandung, Kalam Hidup)

Endang Saryanti, 2011, Kajian Empiris Atas Perilaku Belajar, Efikasi Diri dan KecerdasanEmosional yang Berpengaruh Pada Stress Kuliah Pada Mahasiswa Akuntansi Perguruan TinggiSwasta di Surakarta, Jurnal Ekonomi Bisnis dan Perbankan, 19(18) 2252-7885.

Gunawan, Adi W., Genius Learning Strategy Petunjuk Praktis Untuk. Menerapkan Accelarated Learning, (Jakarta: PT Gramedia Pustaka Utama, 2003)

Haddioui, I. E., \& KHALDI, M. (2012). Learning Style and Behavior Analysis A Study on the Learning Management. International Journal of Computer Applications , 56 (4), 9-15.

Hamruni, H., 2009, Strategi dan Model-model Pembelajaran Aktif Menyenangkan, (Yogyakarta: Fakultas Tarbiyah UIN Sunan Kalijaga)

Hariani, V. 2016. "Kontribusi Gaya Belajar Dan Motivasi Belajar Siswa Terhadap Hasil Belajar Pada Mata Pelajaran TIK Siswa Kelas VIII SMP Kartika 1-6 Padang”, Jumal Pendidikaan UBH, 1(2) 62-75.

Khoeron, I. R. 2014. "Pengaruh Gaya Belajar terhadap Prestasi Belajar Peserta Didik pada Mata Pelajaran Produktif”. Jumal Ilmiah Pendidikan Teknik. Mesin UPI, 1(2), 112-126.

Lampiran: Peraturan Menteri Pendidikan Dan Kebudayaan Nomor 22 TAHUN 2016 tentang Standar proses Pembelajaran.

Ningrat, S. P., Tengeh, I. M., \& Sumantri, M. (2018). Kontribusi Gaya Belajar Dan Motivasi Belajar Terhadap Hasil Belajar Bahasa Indonesia. Jurnal Ilmiah Sekolah Dasar, 2 (3), 257-265.

Nugrahen, E., \& Pangaribuan, N. (2006). Gaya Belajar dan Strategi Belajar Mahasiswa Jarak Jauh: Kasus di Universitas Terbuka. 7 (1), 68-82.

Samples, Bob, 2002, Revolusi Belajar untuk Anak: Panduan Belajar Sambil Bermain untuk Membuka Pikiran Anak-anak. Anda, (Bandung: Kaifa)

Soedijanto Padmowihardjo, Modul: Psikologi Belajar Mengajar, di unduh pada epository.ut.ac.id/4427/1/LUHT4232-M1. pdf, 3 Juli 2019.

Soemanto, Wasty, 2010, Psikologi Pendidikan, (Jakarta: Rineka Cipta)

Soemanto, Wasty. 2006. Psikologi Pendidikan: Landasan Kerja Pemimpin Pendidikan(Cetakan Ke- 5). (Jakarta: Rineka Cipta)

Suryaningsum dkk.(2008). Kajian Empiris Atas Perilaku Belajar dan kecerdasan Emosional dalam Mempengarubi stres Kuliab mahasiswa Akuntansi. Simposium Nasional Akuntansi (SNA) Ke XI Pontianak, 23-24 Juli 2008

Vol. ㄱ. №. [2. kktober 2019

Jurnal Auladuna | 125 
Kajian Konseptual Kontribusi Gaya Belajar

Syah, Muhibbin, 2011, Psikologi Belajar (Jakarta: Rajawali Pers)

Jurnal Auladuna| I26

Vol. OI. No. Q2. Oktober

2019 